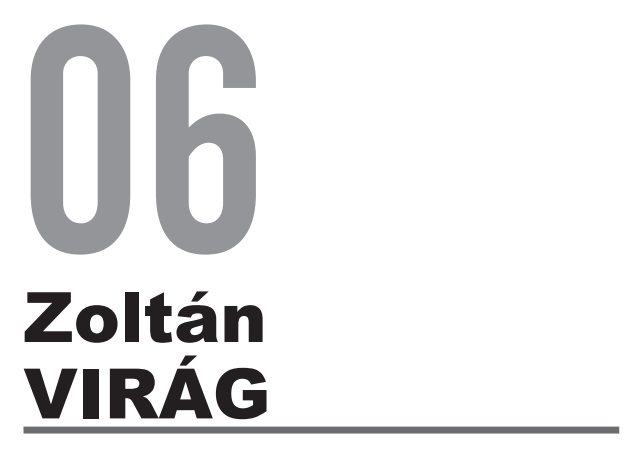

\title{
Segedin
}

Izvorni znanstveni rad

\section{Dublje i od sućuti (O slici Jugoslavije jednog „asketskog sladokusca”)}

G ovoreći o svom gorljivom propagatoru Lászlóu Némethu i zagrebačkom prihatelju Ervinu Sinku, zatim o Ferencu Fejtöu, Miroslav Krleža, kako o tome svjedoči njegov dnevnik, 29. siječnja 1958. godine smatrao je važnim zabilježiti sljedeće: „Fejtőva knjiga Sentimentalno putovanje (1934) negdje mi se zagubila. Bio je to prvi glas iz Horthyjeve Hungarije (....".1. Dodavši u smislu kratke nadopune i pojašnjenja da „Fejtó u Parizu važi danas kao ekspert za balkanska, podunavska i istočnoevropska pitanja."² Pulsirajući ritam i magnetičnu privlačnost staroga Zagreba Ferenc Fejtö je preko rodbinskih veza doživio već u osnovnoškolskoj dobi, a zatim kao mladić. Njegov postupni ulazak u vrijednosni sustav i svakodnevnu pravnu praksu druge kulture te vrtlog njezina živog jezika, različita od vlastitoga, nije se prekinuo ni tijekom odrastanja pa je i dalje izravno utjecao na sve šire otvaranje vrata njegova opažanja svijeta. Gospodarski i socijalni milje hrvatskoga središta upoznao je uranjanjem u osnovna znanja o povijesti, umjetnosti, književnosti i javnog života, te privikavanjem na mjesne modele ponašanja i urbani folklor. Kao čest posjetitelj tijekom praznika, sakupio je dovoljno inspiracije da u budućim au-

1 Miroslav Krleža, Dnevnik 1-5. Prir. Anđelko Malinar. Sabrana djela Miroslava Krleže, (Sarajevo: Oslobođenje, 1977, 2. izd. 1981), str. 32.

2 Krleža, Dnevnik 1-5, 32. 
tobiografskim radovima, esejističkim povijesnim tabloima i novinarskim analizama pronađe svoj odnos prema tom području i voljenom gradu, propuštajući ga kroz filtar stilizirane obrade emocionalnih veza svojih postupaka i obrazovnih simpatija.

Sentimentalno putovanje, djelo duljeg daha izraslo iz Zágrábi utinapló (Zagrebački dnevnik) objavljenog u 11. broju 1935. godišta lista Nyugat, romaneskno je prisjećanje isprepleteno doživljajima i opisima ugođaja s dalmatinske i crnogorske morske obale. Iskoristivši ono najbolje iz žanrovske razgranatosti, agramske utiske iz djetinjstva miješa s nizom teorijskih promišljanja mladića na pragu samoostvarenja, promišljanja o moralnim i etičkim normama, egzistencijalnim mogućnostima građanskog života i latentnim suprotnostima nacija u suživotu. I to oživljavanjem i umetanjem privatnih razgovora koje je vodio s raznim glasovitim osobama na putovanju koje se poziva na popularno djelo Laurencea Sternea (A Sentimental Journey Through France and Italy) iz 18. stoljeća. Piscu koji je napustio rodnu Nagykanizsu, maturirao u matičnoj zemlji u istaknutoj obrazovnoj ustanovi duge tradicije ${ }^{3}$ povjerenoj pijaristima, koju je osnovao palatin Lajos Batthyány, potom studijske godine proveo i Pečuhu i Budimpešti, Zagreb je uvijek ostao mjesto sigurna povratka, ma koliko mu se regionalna klasifikacija, rang i važnost mijenjali. „Zagrebe, ti si moj rodni grad; premda se u tebi nisam rodio, u tvojem se krilu ipak osjećam posve kod kuće. Međutim, tu ne bih mogao opstati, ne bih tu mogao živjeti jer mi je tvoje pučanstvo strano, ono govori drugim jezikom i sudbina mu je, iako slična, ipak toliko drukčija." ${ }^{4}$

Njegovu naklonost prema stanovnicima velegrada koji prima više narodnosti, a prvenstveno prema govornicima hrvatskog jezika zajednički su odredili historijska slojevitost obiteljske prošlosti koja premošćuje granice i zemlje te dramatični obrati sadašnjice 20. stoljeća. Kao svjedok i kroničar uspona i padova razdoblja koja stapaju sudbinska pitanja promatrao je, to jest proživio kretanja, podrobno kategorizirao razvoje događaja i burna zbivanja koja su vodila od kratkotrajna parlamentarnog sustava do monarhističke diktature uzburkane oružanim sukobima i ubojstvima te do vojnog puča, a potom se od staljinističkog pritiska dalje skotrljala do socijalističkoga planskog gospodarstva, da bi odande natrpana skučenom prividnom popustljivošću slobode i tolerancije došla do delirijskog čuda, masovne hipnoze otvorenih državnih granica.

Maloprije spomenuta kao polazište, plemenita krležijanska gesta svojom je karakterizacijom, kojom hvali njegovu međunarodnu reputaciju i odaje prizna-

\footnotetext{
3 Njegovi prethodnici, učenici te najstarije škole u županiji Zala bili su, primjerice, i Benedek Virág, Ferenc Deák, Dezső Malonyai i Sándor Hevesi.

4 Ferenc Fejtö, Sentimentalno putovanje, (Zagreb: Durieux - Dubrovnik: Dubrovnik University Press, 2003), 26.
} 
nje njegovoj obaviještenosti i stručnosti, toliko je imponirala Ferencu Fejtöu da je u Predgovoru s početka novog izdanja Sentimentalnog putovanja objavljenog pedeset i tri godine poslije lijepo uzvratio odavši priznanje svojoj nezaboravnosti: „Veliki Krleža, koji o meni u svojim memoarima govori vrlo ljubaznim riječima, prije nekoliko je godina također zauvijek usnuo." ${ }^{5} \mathrm{Kad}$ je dobrih pola stoljeća prije doznao za postojanje „hrvatskog Remarquea”, na vijesti o njegovoj općepriznatoj umjetničkoj iznimnosti i političkim pogledima koje mnogi osuđuju poželio je doznati kakvi se to sinkronični i dijakronični međuutjecaji nalaze između zagonetna habitusa i revolucioniranih, anarhističkih, marksističkih, komunističkih odmaka i fokalnih nijansi filozofijske obaviještenosti i intelektualne pripadnosti Miroslava Krleže. Unatoč tomu što ga je uzbuđivala izglednost osobnog susreta, da nije morao dvojiti: kad u mraku sadašnjice na stol dospiju temporalna usklađivanja danoga povijesnog razdoblja i individualnoga životnog iskustva, opis suvremenog horizonta te vrednovanje njegovih događaja i stvarnih sudionika uvijek se smatra riskantnim korakom i pokazuje kao iznimno brzoplet mehanizam odlučivanja.

Distancirani spisateljski autoritet, koji nevoljko odgovara na reporterova pitanja, iz isprva ukočenog razgovora iznjedrio je sadržajno malo izlaganje o mađarskoj kulturi, fokusirano na poeziju Endrea Adyja. Utjecaju tog izlaganja Ferenc Fejtö - ma koliko to nastojao prešutjeti - nije se mogao oduprijeti. Čak dva puta navodi s kakvim je istaknutim autoritetom europskog formata imao posla, i premda izričito naglašava kako „u njegove se tekstove uvuklo nešto od iskonske, barbarske, krvožedne gorčine, od očajničkog žara i južnjačke uskipjelosti" ${ }^{\prime \prime}$, on može održati samo privid insiderstva ponašajući se kao da je marljivo uronio u njegov tekstualni svijet, dok na takvoj intelektualnoj marljivosti nije pretjerano ustrajao. „Ibsen s juga” (ne zaboravimo još jedan glasoviti nadimak od mnogih) nije ga zanimao kao pisac lijepe književnosti, već kao tip intelektualca usmjerena na javni život, protuburžujski idol mladih i neumoljiv kritičar vlasti. Koji slobodni stvaralački rad može uzdignuti na pijedestal tako da borbom za neograničenost izražavanja mišljenja i umjetničkog ostvarenja ohrabri pisce istomišljenike i svoje sljedbenike spremne prkositi zabranama; osjećajući odgovornost za simultanost stilova ili upravo oštro progovarajući protiv sovjetizacije kulture, kao što je to javno učinio na III. kongresu Saveza književnika Jugoslavije 5. listopada 1952. godine u Ljubljani. U studenomu iste godine, na IV. kongresu Saveza komunista Jugoslavije, boraveći ondje u izaslanstvu kao izvjestitelj novinske agencije AFP, Ferenc Fejtö ponovno ga je susreo i razgovarao s njim. Premda je čitatelje uglavnom izvijestio o tračevima koji se čine zanimljivima i razveselio ih vicevima o generalissimusu, zacijelo mu ni ove okolnosti nisu ostale nepoznate.

5 Fejtö, Sentimentalno putovanje,12.

6 Fejtö, Sentimentalno putovanje, 163. 
Kad je godinama prije na dan susreta, 23. srpnja izložio svoj plan plovidbe brodom između Rijeke i Kotora, za pomoć je dobio adresu jednog od Krležinih omiljenih likovnih umjetnika i bliskih prijatelja koji je običavao ljetovati u Mlinima pored Dubrovnika. U Fejtövim djelima nalazimo i sažetu i podrobnu inačicu priče; prvo ju je prikazao u gruboj skici kao avanturistički lutalica Sentimentalnog putovanja, a drugi ju je put naveo u knjizi Memoari: Od Budimpešte do Pariza preko Zagreba, brižno dokumentirajući izostavljene epizode i temeljitije secirajući momente ostavljene u mraku. A kad govori o umjetniku apostrofiranom kao "najveći živući jugoslavenski slikar" i navedenom samo inicijalima njegova imena (P. D.) te o srdačnoj razmjeni misli njih dvojice, - možda zbog političke predostrožnosti ili osjećaja prijetnje cenzure - pribjegava zagonetnim i diskretnim tvrdnjama. Navodi, primjerice, da je dotični „u jednoj srednjoeuropskoj državi zbog revolucionarna djelovanja osuđen na smrt"8 i koji je došavši u francusku prijestolnicu „mnogo vremena provodio među Mađarima [te iskazavši zanimanje] za mladoga pjesnika s velikom Adamovom jabučicom, grmovite kose, obješenjačke vanjštine" ${ }^{\prime \prime}$ pobliže se upoznao i u više navrata s njime provodio vrijeme.

Endre Angyal uspio je zapaziti ovu vijest o vizitaciji koju je nadahnuo Krleža. On je odgonetnuo monogram Petra Dobrovića, poetu koji je iskrsnuo u Parizu lako je identificirao kao Attilu Józsefa, odnosno korigirao je stvarne činjenice vezane za domaćina koji se također predstavlja kao Petar Dobrović, to jest Dobrovits/Dobrovics Péter, podrijetlom iz Pečuha, predsjednika kratkovjeke Baranjsko-Bajske Srpsko-Mađarske Republike (14. kolovoza 1921.-21. kolovoza 1921), proglašene nakon srpske okupacije toga rudničkoga grada: „Dobrović nikad nije osuđen na smrt, a ni pečuški vojni ustanak nije organizirao on, već je u njemu samo sudjelovao. Vjerojatno se i razgovor odvijao na mađarskom jeziku, a ne na francuskom, naime, jezik je razumjela i mlada gospođa Olga, podrijetlom Vojvođanka."10 Memoari: Od Budimpešte do Pariza preko Zagreba, najprije objavljeni 1986. godine na francuskom jeziku, kao i nadopunjene inačice na mađarskom jeziku (1990, 2007) mnogo su opsežniji, privremeni odmor u Mlinima zadobiva preciznije i šire činjenične okvire, te ih točnost podataka i konkretizacija imena čine zaokruženijom cjelinom. Ferenc Fejtö je iz glasina i posrednih informacija (zahvaljujući prijatelju Csabi Nagyu) doznao za rezultat istraživanja zaslužnog slavista, premda ga je pogrešno nazvao Imre Angyal (na sramotu urednika knjige i prevoditelja tako je i zabilježeno), a kao žalostan ishod navedenoga čak ni podnaslov te važne disertacije nije riješen

\footnotetext{
7 Fejtö, Sentimentalno putovanje, 220.

8 Fejtö, Sentimentalno putovanje, 219.

9 Fejtö, Sentimentalno putovanje, 221.

10 Endre Angyal, Petar Dobrović, Az ember, múvész és politikus (Pécs: Magyar Tudományos Akadémia Dunántúli Tudományos Intézete /Közlemények 3./,1968), 53.
} 
na odgovarajući način, naime, krivo je citiran jer ga autor (umjesto „čovjeka, umjetnika i političara”) navodi kao „čovjeka, slikara i političara”.11

Prvu potpuniju karakterizaciju o Petru Dobroviću producirao je István Tamás, izvorno vezan za Pécsvárad, koji se zatekao u Parizu dvadesetih godina i s njim se upustio u dijalog, u zbirci razgovora kojoj je uvod predgovor Dezsőa Kosztolányija: „Sama vatra, zanos i aktivnost. Kako govori, kako gestikulira, posve ga preplavljuje nemir borbenih vremena, koji ga je bacio na čelo pokreta koji je čovjeka sa srcem od lave bacio iz svijeta fantazije na cestu realnosti podstavljenu mačevima i bajunetima. Bizarne li ideje: poetski slikar s puškom u ruci, a iza njega gomila spremna umrijeti. Vidio sam njega 1921. godine u Pečuhu, onoga povijesnog dana kada su se svi narodi rudnika udružili pod njegovom zastavom, odbacio je svoj kist i proveo bravurozan pokret kakvom nema premca u povijesti likovne umjetnosti."12 Minijaturni panegirik tog dijela karijere, dakako, nije zaobišao ni njegovu poetsku privrženost vještini zemljaka: „Nikada nisam slikao krajolike izvan svog zavičaja, jedinu iznimku učinio sam i činim s Dalmacijom. Fantastično lijepi gradovi, mramorne palače još iz 12. pa do 18. stoljeća. Ponosna romantika stvorena za slikara!"13 Dakako, s gledišta povezanosti njih trojice zadunavskom ingerecijom još je uočljivije s kakvim se opuštenim uranjanjem, glatkim smještanjem kod Fejtöa ocrtava umjetnički postupak odbacivanja grafizma koji razgraničava forme, kao i Dobrovićeva iznimnost slikovne artikulacije opažaja boje i materije ${ }^{14}$. S Olgom Hadži, izabranom za muzu i model, kao vječnom zrakom Sunca u središtu, koju putnik očaran jadranskim obalnim krajolikom naziva suprugom „koja se drži poput Mone Lise”15, nalik „srpskoj Giocondi”16, što u djelu Memoari: Od Budimpešte do Pariza preko Zagreba dopunjava s ustrajnim divljenjem čarima mlade gospođe, nalik „pravoj Bourdelleovoj skulpturi”. ${ }^{17}$

Glavni junak djela Sentimentalno putovanje na hodočašću kroz mediteranske predjele s velikom se otvorenošću i prijemčivošću kreće mini-rajem Mlina, preoblikovanim iz vodenica, u arkadijskoj viziji18 čežnje za radostima blagostanja, obilja i mira. Njegov se senzibilitet ne iskazuje samo u činjenici da je postao strastvenim pristašom i modernim sljedbenikom djela Laurencea Sternea, koje

\footnotetext{
${ }^{11}$ Ferenc Fejtő, Budapesttől Párizsig - Párizstól Budapestig: Visszaemlékezések és beszélgetések, ford. Péter Balabán (Budapest: Kossuth Kiadó, 2007), 158.

12 István Tamás, „Petar Dobrovics”, in T. M., 5 világrész a Szajna partján (Subotica: Minerva RT., 1927), 163.

13 István Tamás, „Petar Dobrovics”, 162.

14 Usp. Ješa Denegri, „Petar Dobrović i Dubrovnik”, in J. D., Modernizam/Avangarda: Ogledi o međuratnom modernizmu i istorijskim avangardama u jugoslovenskom umetničkom prostoru (Beograd: Službeni glasnik, 2012), 86.

${ }^{15}$ Ferenc Fejtö, ,Sentimentalno putovanje, 222.

${ }^{16}$ Ferenc Fejtö, Sentimentalno putovanje, 223.

17 Francois Fejtö, Memoari: Od Budimpešte do Pariza preko Zagreba, (Zagreb: Nakladni zavod Matice hrvatske, 1989), 76.

18 Usp. Denegri, „Petar Dobrović i Dubrovnik”, 86.
} 
je Ferenc Kazinczy preveo na mađarski kao Érzékeny útazások Franczia- és Olaszországban (Osjetljiva putovanja po Francuskoj i Italiji), nego i u njegovim reakcijama pobuđenima tim svježim artističkim impulsima i umjetničko-psihoIoškim izazovima. „Mislimo da je Fejtö ovdje dobro shvatio cjelokupni habitus Dobrovića kao čovjeka, umjetnika i političara. I u opisu susreta i razgovora veoma je dobar prikaz okoline, dalmatinskog ambijenta koji inspirira slikara, odnosno samog umjetnika, njegove vanjštine i osobnosti"19 - naglasio je Endre Angyal govoreći o toj uvjerljivo razvijenoj sitničavosti i stručnosti.

Razinu bratske dosljednosti okretanja prema drugomu i opredijeljenosti za oblikovni pristup povećava činjenica da je ona u pogledu obrade teme, pa čak i s obzirom na estetsku zahtjevnost u suzvučju s umjetničkom samoanalizom i vlastitom inicijacijom - koja rasvjetljuje atelijerske tajne - koje su se proslavile iz usta Petra Dobrovića, po očevoj liniji također podrijetlom iz Nagykanizse. O tome duševnom rudarenju vezanom za vlastiti nazor doznajemo preko Miroslava Krleže, naime, u memoarima koji se vraćaju na agramsko djetinjstvo (Djetinjstvo u Agramu 1902-03, Zagreb, Zora, 1952) on je kao autentičan posrednik izvijestio o vjeroispovijesti njegova umjetničkog suvremenika i prijatelja, što je evociranjem karakterističnih rečenica ukratko ponovio doslovno u maloj monografiji posvećenoj njegovu opusu (Petar Dobrović, Zagreb, Zora, 1954). Prema tumačenju svjedoka „Petar Dobrović je govorio: Slika je za mene koloristična masa. Ja gledam u istu kolorističnu masu i na objektu koji slikam, i ja ne aranžiram sliku, ja je prenosim onako kako mislim da ona doista postoji. Intenzifikacija kolorističkih masa na objektu, to je moj program pod svaku cijenu. [...] Ljudima ne laskam do tog stepena da sam ih spreman uvijek karikirati. Čovjek je preda mnom arhitektonska pojava sa manje važnim psihološkim momentima u rasvjeti koju dižem u intenzitetu dok mogu." 20

Ulomci Ferenca Fejtöa koji stavljaju pod povećalo glavne znakove raspoznavanja, izvanjske značajke, spiritualna titranja, razlike u temperamentu i nagonskom životu etnikā nastanjenih u južnoslavenskom području služe se uobičajenim stereotipijama s naklonošću, ali ne bez fantazije, kroz poopćenja koja dokazuju neslomljivu volju za otporom i revolucionarni patos poletnih Hrvata, neustrašivost i nepotkupljivost žestokih Srba, umjerenost i europsku obrazovanost ponosnih Slovenaca, te neusporedivu tvrdoglavost i podmukli um skriven iza širokih gesta Crnogoraca. Pri susretu koji pobuđuje zanimanje puno suosjećanja „pojavljuju se ljudi, često kao bezlična masa, ali se također nerijetko dešava da se pojedinac izdvoji iz skupine, poprima specifične osobine, čak dolazi do verbalnog kontakta između njega i pisca."21 Oscilacije

\footnotetext{
19 Angyal, Petar Dobrović, 53.

20 Miroslav Krleža, Djetinjstvo u Agramu 1902-03, (Zagreb: Zora, 1952), 386.

21 Franciska Ćurković-Major, „Zágráb képe Fejtő Ferenc Érzelmes utazás című regényében”, Tiszatáj 56, 10 (2002): 81.
} 
društveno-političke strukture, odnosno ponovnu uspostavu ili mogućnost ponovna stvaranja temeljnih situacija održanja zajednice nastojao je ispitati u zrcalu ratnih konflikata i lažne međuetničke tolerancije. Snažan nacionalistički karakter političkih elita proučavao je zabrinut zbog popuštanja i devalvacije vrijednosti socio-moralnih veza. Promišljajući kroz desetljeća, obuhvativši i lice i naličje, sve ono što se kao posljedica vezanosti za većinske i manjinske statuse te promjena centralnih i perifernih pozicija odvilo na štetu njemu tako dragih Hrvata te pogoršavši nevolje mađarskog stanovništva u Bačkoj, Banatu, Slavoniji, Baranji i Međimurju doprinijelo teritorijalnoj agoniji pojasa koji je, oduvijek smatran buretom baruta, promijenio razne vlasti i različite državne ustroje.

Kod njega se iz balkanske dimenzije krajnosti uočljivo ističu još dva kultna lika. U četvrtom dijelu Memoara: Od Budimpešte do Pariza preko Zagreba (Pokušajmo živjeti), nadalje u razgovoru iz 2006. godine priloženom posredstvom Béle Gallóa i Lászla Mártona, pod naslovom Od Pariza do Budimpešte, kao i u njegovim stručnim komentarima i povijesno-političkim promišljanjima objavljivanima od druge polovice 1950-ih u listu Irodalmi Ujság, 1990-ih godina u listovima Heti Kis Újság i Európai Utas, a u desetljeću njegove smrti u listu Magyar Hírlap u mnogo se navrata pojavljuje lik Josipa Broza Tita i njegova nekadašnjeg zamjenika, Milovana Đilasa. Njihov proturječni životni put ocrtava se iz slika trenutaka nalik portretima, suštinskih opaski, ali i smiona odabira mrvica informacija i intimnih dodataka koji ukazuju na osobne neksuse. Emblematski partizanski vođa, balkanski moćnik koji paradira u raskošnim odijelima i basnoslovno skupim svečanim odorama, iz čije se željezne šake skrivene u baršunaste rukavice protivnik itekako dvojbeno mogao osloboditi, s uspostavom mira koji je ublažio vjersku mržnju, s očinskim stavom kojim je privukao sve Jugoslavene, dakle sa svemoći koju je crpio iz izmišljotine svenarodskog obožavanja ${ }^{22}$ sâm utjelovljuje pseudodemokraciju relativne otvorenosti i krute uređenosti.

Hvalisav i gizdav lik Tita, od oca Hrvata i majke Slovenke, u osobitu je kontrastu s crnogorskom odlučnošću Milovana Đilasa, kojeg odlikuje oštar um i žestok temperament. Povoljnu sudu njegove uloge mnogo je doprinijela činjenica da je njegovo stajalište, koje je od 1947. godine naglašavao kako pred užim plenumom tako i na javnim forumima, o pružanju podrške mađarskoj demokraciji i pomaganju pobjede u srednjoeuropskim mjerilima uvelike bilo u skladu s Fejtövim zamislima. Ni njegova pomoć u stvaranju i provedbi sugestije pokrajinskoga narodnog ujedinjenja i sjedinjenja nije bila zanemariva jer „unutarnje granice jugoslavenske federacije odredila je 1945-1946. komisija

22 Usp. Vjekoslav Perica, „United We Stand, Divided We Fall: The Civil Religion of Brotherhood and Unity", in V. P., Balkan Idols: Religion and Nationalism in Yugoslav States (New York: Oxford University Press, 2002), 103. 
pod vodstvom Milovana Đilasa". ${ }^{23}$ Njegova koncepcija o zemlji koju će ustrajni rad naroda i narodnosti uz njihovu međusobnu podršku bratski stopiti u novim, slavnim sadržajima jugoslavenskog osjećaja i promišljanja nije bila manje osvježavajuća oko 1953. godine. Međutim, doznavši za titoističke krvave odmazde te primivši s neodobravanjem probleme uzrokovane revolucionarskim monopolom nove partijsko-birokratske elite ubrzo je morao konstatirati da je Đilasa, koji je osuđivao jugoslavenske društvene prilike, „samovlast i tiraniju administrativnog aparata"24 i zagovarao nužnost osnivanja jedne oporbene političke stranke, Sud u Beogradu 1955. godine osudio na godinu i pol (s tri godine uvjetno) pod optužbom širenja agitacijske propagande. Nakon toga su 1956. godine uslijedili uhićenje i kazna strogog zatvora zbog njegova mišljenja kojim je osudio jugoslavenski stav po pitanju sovjetske okupacije Mađarske, jer je nastupio izvrčući činjenice i s namjerom klevete kako bi narušio ugled vlastite zemlje i povrijedio interese njezinih naroda. Nije mu ostalo mnogo vremena za probaviti te odluke dok je bio u zatvoru u Sremskoj Mitrovici, naime, zbog knjige tiskane u Velikoj Britaniji i Sjedinjenim Američkim Državama (The New Class: An Analysis of the Communist System, London, Thames and Hudson, 1957) mjesni općinski sud natovario mu je još dvije godine.

Milovan Đilas, uhićen u studenom 1956. godine i otada držan iza rešetaka, pušten je uvjetno 20. siječnja 1961. godine. Tomu u čast Ferenc Fejtö u pozdravnom tekstu iskazuje kako je on „oštro osuđivao nemoralno ponašanje sovjetskih »oslobodilačkih « trupa, agresivnost pijanih časnika i aroganciju sovjetskih "stručnjaka« izaslanih u Jugoslaviju", ${ }^{25}$ i ne skriva da se taj, čije aktualno oslobođenje slavi, ističe među svojim suvremenicima i političkim kolegama „kao tip čovjeka koji govori otvoreno, iskreno vjeruje u komunističke ideale, ali nije zaslijepljen ideologijom, koji se suočava sa stvarnošću i istinu cijeni više nego svoja načela"26. Dakako, kao ljevičar koji traga za slobodom već je 1957. godine sve prozreo, naime, svojedobno je otkrio pozadinske poveznice represivnih pravila te prisilnih i nužnih rješenja u razdoblju nakon izvlačenja iz ratnog komunizma: „Stvarnost je međutim ta da od 1945. godine komunistički partizanski vođe, koji su iz građanskog rata izišli kao pobjednici, drže svaku značajnu političku, gospodarsku i kulturnu poziciju jugoslavenske države pod okupacijom. Oni su glavni dužnosnici ministarstava, direktori banaka, direktori tvornica, o policijskim i vojnim časnicima da i ne govorimo. Pod imenom

\footnotetext{
${ }^{23}$ Dinko Šokčević, Hrvatska od stoljeća 7. do danas, (Zagreb: Durieux i Društvo mađarskih znanstvenika i umjetnika u Hrvatskoj, 2016), 482.

${ }^{24}$ Darko Suvin, „The Socialist/Communist Discourse about Bureaucracy /Appendix 2: The Discourse about Bureaucracy and State Power in Post-Revolutionary Yugoslavia/", in D. S., Splendour, Misery, and Possibilities: An X-Ray of Socialist Yugoslavia (Leiden - Boston: Brill, 2016), 351.

${ }^{25}$ Ferenc Fejtő, „Gyilasz szabadon”, Irodalmi Ujság 12, 3. veljače (1961): 3.

${ }^{26}$ Fejtő, „Gyilasz szabadon”, 3.
} 
jugoslavenske proleterske diktature zapravo se provlači partizanska diktatura. To je specifičnost njihova sustava u odnosu na ruski i druge komunističke sustave; to mu daje nacionalni značaj, kao što zajedništvo bivših partizana koji su postali administratorima osigurava gotovo iznimnu stabilnost sadašnjega jugoslavenskog režima". ${ }^{27}$

Nije se činilo teškim dokučiti lukavstvo jugoslavenske vlade koja je puštanjem Milovana Đilasa pribjegla praksama pobuđivanja zabluda. Željela je domaćem i inozemnom javnom mnijenju prodati tezu da je puštanje "pionira radikalne pobune" 28 na slobodu zapravo spasonosni ishod dobre namjere i demokratske prakse upravljačke vlasti, to jest da ni u kom slučaju nije neko izolirano riješeno i razriješeno pitanje, već samo djelomičan razvoj događaja, predigra društvene reintegracije osoba držanih pod lokotom zbog političkih razloga. Stoga je Ferenc Fejtö na vijest o ponovnom uhićenju „crnogorskog fakina"29 zbog njegove knjige Razgovori sa Staljinom (Conversations with Stalin, New York, Harcourt Brace Jovanovich, 1962) i kazni od, zbrojivši petogodišnju kaznu s prethodnom, ukupno trinaest godina zatvora mogao reagirati zapanjen samo zakonskim odredbama ciljano smišljenima za obuzdavanje đilasovske renitentnosti: „ma kakve pravne argumente navede državni i partijski rezon za opravdanje svoga postupka, činjenica je da opet stavljaju brnjicu čovjeku čija su otvorenost i hrabrost te strastvena istinoljubivost dosad donijeli samo slavu njegovu narodu i domovini". ${ }^{30}$

Civilna odvažnost Milovana Đilasa, njegovo napadanje životnog stila komunističke nomenklature i to što su buržujski intelektualci upijali njegove riječi, a mase studenata ga obožavale vjerojatno su se iznimno svidjeli Ferencu Fejtöu, ne u posljednjem redu zbog toga što je upravo sve to smetalo Josipu Brozu Titu i pobuđivalo u njemu čudovišan bijes. Njegovi članci objavljeni 1960-ih godina u listu Irodalmi Ujság bave se temama kao što su: samoopravdanje jugoslavenskoga neutralnog usmjerenja po pitanju industrijske izolacije i poboljšanja tržišno-gospodarskih pokazatelja, u članku A jugoszláv gazdasági elképzelések (Jugoslavenske gospodarske zamisli) od 15. svibnja 1962; sovjetsko popuštanje koje prigrljuje Savez komunista Jugoslavije kao sestrinsku stranku i unatoč njezinu koketiranju s imperijalistima, u članku Hruscsov Titót választotta (Hruščov je odabrao Tita) od 1. siječnja 1963; maršalski plesni koraci odigrani sa Zapadom i Amerikom kao predan partner, u članku A jugoszláv kommunisták kongresszusa (Kongres komunista Jugoslavije) od 1. siječnja 1965; te makinacije kojima režim koji maltretira neistomišljenike sprečava manifestacije i ukida ili zabranjuje književne i umjetničke časopise,

\footnotetext{
${ }^{27}$ Ferenc Fejtő, „Belgrádi levél”, Irodalmi Ujság 8, 1. kolovoza (1957): 2.

28 Suvin, „The Socialist/Communist Discourse about Bureaucracy”, 352

${ }^{29}$ Ferenc Fejtő, „Gyilasz”, Irodalmi Ujság 13, 15. travnja (1962): 5.

30 Fejto”, "Gyilasz”, 5.
} 
u članku Jugoszlávia fordulóponton (Jugoslavija na prekretnici) od 15. siječnja 1965. godine. Autori i uredništvo slovenskog magazina Perspektive (Fejtövom pogreškom zapisano: „Perspektiva”) optuženi su za obranu vrijednosti građanskog života, želju za ponovnom uspostavom višestranačkog sustava, pa i povjerenje i ljubav koju su im iskazali ljubljanski radnici u štrajku i studenti bijesni zbog linijske državne uprave, za što su nužno morali ispaštati dvojica priznatih pisaca. Tomaž Šalamun i Marjan Rožanc (naš autor doduše spominje prezime potonjega, no dijakritičkom znaku ni traga ni glasa) ustaljenom su separacijom provedbe kazne povučeni iz prometa.

Iracionalnost jugoslavizma, jugonacionalizma, nacionalnog komunizma i etničkog integralizma nikad nije bila upitna Ferencu Fejtöu, naime, ni sam nije ozbiljno vjerovao u postojanje edenskog vrta multikulturalnosti. U Jugoslaviji, kao razmaženom posvojčetu Zapada i SAD-a, u njezinoj privilegiranosti obilja i šarolikosti koja bezbrižno dozira mješavinu vesele zabave Disney Worlda i Legolanda dano je gotovo sve što oči i usta požele. No u kavalkadi omeđenoj ukrasima napukle glazure, usred čahurenja u plastičnu zaštitnu ovojnicu tamošnji su narodi morali proći kroz nebrojene kušnje, na njima je isprobano sve što se pokazalo rješivim na egzistencijalnom, jezično-kulturnom području, sa svjetonazorskim, gospodarsko-organizacijskim i društveno-planskim ciljem i bacanjem u zanos državne obrane i naoružavanja. Nije slučajno jedan prominentni slovenski pisac i intelektualac koji je poticao na kolektivno buđenje 1991. godine definiciju "Titoslavije”, oznaku "Titoland” smatrao opravdanom za detronizirajući, strog naziv ${ }^{31}$ državne tvorevine koja je nakon gotovo tričetvrt stoljeća postojanja došla do svog raspada.

Diplomatska filantropija i pacifistička orijentiranost Ferenca Fejtöa, koji je često spominjao svoje socijaldemokratsko opredjeljenje, marksizam, preobrazbu svoga mađarskog patriotizma u militantno europsko domoljublje, kao i svoju kozmopolitsku srčanost, sa starim su zanosom i uzvišenošću uzele maha 1990-ih godina, kad u listu Heti Kis Újság raščlanjuje sveopće ludilo nacionalkomunizma, militantnu teritorijalnu podjelu i istrebljivanje susjeda na osnovi podrijetla ili vjeroispovijesti, kao u članku A szerb nemzeti kommunizmusról /Az „etnikai tisztogatás” ideológiai forrásai/ (O srpskom nacionalkomunizmu /ldeološki izvori "etničkog čišćenja”/) od 7. svibnja 1993. godine. Kao prosvjetiteljski humanist koji osuđuje hegemonističke težnje za uništenjem nakane osamostaljenja, te odbacuje gaženje tradicija i zanemarivanje ljudskih prava, pripadao je onima koji su u solidarnosti s Hrvatima „prepoznali [...] opasnost u Miloševićevim težnjama i podupirali su pitanje

\footnotetext{
31 Usp. Drago Jančar, „Emlékek Jugoszláviáról”, ford. Orsolya Gállos, in Az eltört korsó: Válogatás a legújabb szlovén esszéirodalomból ford. Orsolya Gállos, Judit Reiman (Pécs: Jelenkor Irodalmi és Múvészeti Kiadó, 1992), 114, 121.

32 Šokčević, Hrvatska od stoljeća 7. do danas, 550.
} 
hrvatske neovisnosti”. ${ }^{32} \mathrm{U}$ intervjuu koji je dao listu Magyar Hírlap, pod naslovom „A szerbek vesztettek” ("Srbi su izgubili”) od 14. lipnja 1993. godine, odgovarajući Hanni Szalay, kao jamstvo srednjo-istočno-europskog napretka naveo je federaciju po scenariju koji forsira Zapad, demokracije koje bi pojedinačno izrasle na razini republika članica. Kao rješenje problema ovdje se pokazuje mladenački zagrebački ideal vezan za jamca hrvatskog suvereniteta, Vladka Mačeka, koji je poticao na pobunu protiv centralističke vlasti i pasivni otpor.

Na samom kraju 1930-ih godina „postizanje [hrvatsko-srpskog] sporazuma bila je zasluga Vladka Mačeka, političara Seljačke stranke"33, na što posredno već samim naslovom ukazuje kratka analiza objavljena u jednom od ljetnih brojeva lista Magyar Hírlap 2001. godine, o izgledima sporazuma po pitanju zamršene situacije u Bosni. Njegovo shvaćanje sposobnosti vanjskih poslova nadležnih organa i kompetencije Zapada sada je bitno suzdržanije i umjerenije, što je godinama prije nagovijestila spoznaja koja ukazuje na istrošenost kapitala povjerenja: „Jugoslavenska tragedija najjasnije rasvjetljuje do kakvih strahota može dovesti kad se birokratskim i vojnim sredstvima iskoristi - pokopanom smatrana - strast za vlastohlepljem i ksenofobijom, koja proizlazi iz društvenih i gospodarskih nevolja i nedostatka demokratskog nazora." ${ }^{44} \mathrm{Hr}$ vatske i slovenske težnje za autonomijom te velikosrpska ekspanzijska nastojanja konačno su raspršili fatamorganu jugoslavenskog saveza, stoga se polako morao pomiriti s činjenicom da san o federaciji u najboljem slučaju može funkcionirati kao anakronizam željan iluzije. Došao je kraj „vjeri da se trajni mir može stvoriti bez pitanja narodā, povredom prava nacionalnog samoodređenja i nepoznavanjem povijesne situacije". ${ }^{35}$ Stupanje u vojsku, oružano nasilje, laviranje između suprotstavljenih strana, kao što su članovi slovenskoga umjetničkog i glazbenog sastava Laibach upozorili s averzijom prema mjerama predostrožnosti nepromišljeno uvedenima radi očivanja Jugoslavije koja je postala "metaforom okrutnosti bez premca”"36 i prema međunarodnim uplitanjima koja se međusobno natječu: „Zdravo je za bogate, a smrtonosna bolest za siromahe. Rat je kapitalizam svučenih rukavica”. ${ }^{37}$ Sa zlobnošću prilagođenom „rotaciji koja širi maštu, vizualnih reprezentacija moderne i postmo-

\footnotetext{
33 Šokčević, Hrvatska od stoljeća 7. do danas, 399.

${ }^{34}$ Ferenc Fejtő, „Nemzetek, kisebbségek, Európa”, ford. Anna Osvát, Európai Utas 5, 3 (1994): 15.

${ }^{35}$ Ferenc Fejtő, „A horvát - szerb megegyezés”, Magyar Hírlap, 8. lipnja (2001): 7.

36 Vladimir Unkovski-Korica, "Conclusion” in V. U-K., The Economic Struggle for Power in Tito's Yugoslavia: From World War II to Non-Alignment (London - New York: I. B. Tauris \& Co. Ltd 2016), 231.

37 „Kérdések a Laibach csoportnak (A Rockerilla magazin nyomán)”, ford. Tamás Domokos in Extázis és agónia: Független zenei /h/arcterek, a Fosszília különszáma (VII. évf. 4.), vál. és szerk. Zoltán Virág (Szeged: JABE a Hallgatókért Kiadói Alapítvány - POMPEJI Alapítvány, 2006), 156.
} 
derne (meta)pripovijesti raznolika učinka"38, na svoju zastavu postavljaju misli vodilje i gesla koja odzvanjaju vojničkim heroizmom: „TATI - TITO - TOTO NATO"39 euroatlantskog standarda nadziranja naroda i smirivanja konflikata provedenih vi et armis.

U eri širenja nabujalih provincijalizama sve je to bilo popraćeno i time da je u više ciklusa potrage za identitetom, u kojima se vjerovanje prema kojemu „se čovjek po svaku cijenu mora ograničiti samo na jedan identitet"40 nikad nije činilo održivim kao pravilo, Ferencu Fejtöu polako se iskristaliziralo: u tampon područjima geografskog predjela koji je u djetinjstvu zadobio i nepromjenjivo zadržao njegovu naklonost još nije otkrivena nacionalna i egzistencijalna sigurnost bez države. Kao ni supranacionalizam, patriotizam bez ideologije, već samo povrede interesa proizišle iz ostavštine burne prošlosti i napukloga gospodarskog ostvarenja narod(nos)nih grupiranja te opterećenost sektorskim napetostima koje izviru iz vrtloga rutinskih optuživanja. Tako su stupanj i stratifikacije strastvena suosjećanja koje povijesne lekcije poučavaju, obiteljske tradicije i njihovi pokretači diktiraju, a intelektualno-kulturne pobude napajaju vrijedni posebne pozornosti. S rijetkim je predosjećajem naslutio da su mehanizmi tehnike vlasti Jugoslavije pod vodstvom i ostavštinom Josipa Broza Tita te idoliziranje blagostanja koje jamči optimističnu budućnost stvorili nostalgičnu simulaciju samih sebe, te je sumnjao da perfekcionistički snovi o savršenim vođama, odnosno iskustva južnoslavenskih ratova ukazuju na to da ovakvo stvaranje vrijednosti i nostalgija mogu živjeti isključivo u narativima idealiziranosti, te potrebitima ponuditi oslonac i pružiti nešto utjehe samo kao utopija ${ }^{41}$.

Prevela Lea Kovács

\footnotetext{
${ }^{38}$ Mitja Velikonja, „New Yugoslavism in Contemporary Popular Music in Slovenia”, trans. Olga Vuković in Post-Yugoslavia: New Cultural and Critical Perspectives, ed. Dino Abazović and Mitja Velikonja (Basingstoke: Palgrave Macmillan, 2014), 69-70.

39 „Kérdések a Laibach csoportnak..., 157.

${ }^{40}$ Fejtö, Sentimentalno putovanje, 13.

${ }^{41}$ Usp. Velikonja, „Mapping Nostalgia for Tito: ..., 194-195.
} 


\section{Literatura}

Angyal, Endre. Petar Dobrović: Az ember, múvész és politikus. Pécs: Magyar Tudományos Akadémia Dunántúli Tudományos Intézete /Közlemények 3./, 1968.

Ćurković-Major, Franciska. „Zágráb képe Fejtő Ferenc Érzelmes utazás című regényében". Tiszatáj 56, 10 (2002): 77-87.

Denegri, Ješa. Modernizam/Avangarda: Ogledi o međuratnom modernizmu $i$ istorijskim avangardama u jugoslovenskom umetničkom prostoru. Beograd: Službeni glasnik, 2012.

Fejtő, Ferenc. „Belgrádi levél”, Irodalmi Ujság 8, augusztus 1. (1957): 2.

Fejto, Ferenc. „Gyilasz szabadon”, Irodalmi Ujság 12, február 3. (1961): 3

Fejtő, Ferenc. "Gyilasz”, Irodalmi Ujság 13, április 15. (1962): 5.

Fejtö, Francois. Memoari: Od Budimpešte do Pariza preko Zagreba. Zagreb: Nakladni zavod Matice hrvatske, 1989.

Fejtő, Ferenc. „Nemzetek, kisebbségek, Európa”. Ford. Anna Osvát, Európai Utas 5, 3 (1994): 14-15.

Fejtő, Ferenc. „A horvát-szerb megegyezés”. Magyar Hírlap, június 8. (2001): 7.

Fejtö, Ferenc. Sentimentalno putovanje. Zagreb: Durieux, Dubrovnik: Dubrovnik University Press, 2003.

Fejtő, Ferenc. Budapesttől Párizsig - Párizstól Budapestig: Visszaemlékezések és beszélgetések. Ford. Balabán Péter, Budapest: Kossuth Kiadó, 2007.

Jančar, Drago. „Emlékek Jugoszláviáról”. Ford. Orsolya Gállos. In Az eltört korsó: Válogatás a legújabb szlovén esszéirodalomból. Ford. Orsolya Gállos, Judit Reiman, Pécs: Jelenkor Irodalmi és Művészeti Kiadó, 2002.

„Kérdések a Laibach csoportnak (A Rockerilla magazin nyomán)”. Ford. Tamás Domokos. In Extázis és agónia: Független zenei /h/arcterek, a Fosszília folyóirat különszáma, vál. és szerk. Zoltán Virág, Szeged: JABE a Hallgatókért Kiadói Alapítvány - POMPEJI Alapítvány, 2006.

Krleža, Miroslav. „Djetinjstvo u Agramu 1902-03”. Zagreb, Zora, 1952.

Krleža, Miroslav. Dnevnik 1-5. Prir.: Anđelko Malinar. Sabrana djela Miroslava Krleže, Sarajevo: Oslobođenje, 1977. (2. izd. 1981.)

Krleža, Miroslav. „Napló 1958-1969: részletek”. Vál. és ford. Gábor Túri, Híd 46, 7-8 (1982): 849-936.

Perica, Vjekoslav. Balkan Idols: Religion and Nationalism in Yugoslav States. New York: Oxford University Press, 2002.

Šokčević, Dinko. Hrvatska od stoljeća 7. do danas. Zagreb: Durieux i Društvo mađarskih znanstvenika i umjetnika u Hrvatskoj, 2016. 
Suvin, Darko. Splendour, Misery, and Possibilities: An X-Ray of Socialist Yugoslavia. Leiden-Boston: Brill, 2016.

Tamás, István. 5 világrész a Szajna partján. Subotica: Minerva RT., 1927.

Unkovski-Korica, Vladimir. The Economic Struggle for Power in Tito's Yugoslavia: From World War II to Non-Alignment. London-New York: I. B. Tauris \& Co. Ltd., 2016.

Velikonja, Mitja "New Yugoslavism in Contemporary Popular Music in Slovenia". Trans. Olga Vuković. In Post-Yugoslavia: New Cultural and Critical Perspectives. edited by Dino Abazović and Mitja Velikonja, Basingstoke: Palgrave Macmillan, 2014.

Velikonja, Mitja. 2015. „Mapping Nostalgia for Tito: From Commemoration to Activism". In Welcome to the Desert of Post-Socialism (Radical Politics After Yugoslavia), edited by Srećko Horvat and Igor Štiks, London-New York: Verso Press, 2015.

\section{A részvétnél is mélyebbre (Egy aszketikus ínyenc Jugoszlávia-képéről)}

A gondolatmenet Fejtő Ferenc önazonosság-keresésének, intellektuális tájékozódásának és politikai szimpátiáinak összefüggéseit vizsgálja. A szerző ama koncepciójának szellemi-kulturális körvonalait szemügyre véve, amelyben térségünk különleges regionális tagoltságú, huszadik századi metaforikus szerveződésként jelenik meg. Mégpedig a szerényebb méretekre és a gyengülő gazdasági hátterű függőségekre kárhoztatott nemzet(ség)i csoportosulások historikus örökségének konglomerátumaként. Kiemelt hangsúlyt kap az a fejtői sejtés, hogy a Josip Broz Tito-i vezérlésű és örökségű Jugoszlávia hatalomszervezési, nyelvi-retorikai mechanizmusai voltaképpen önmaguk nosztalgikus szimulációját hozták létre. Ám a tökéletes államról és a tökéletes vezető(k)ről szőtt perfekcionista álmok, valamint a délszláv háborúk tapasztalatai arra utalnak, az ilyesfajta értékképzés és visszavágyódás kizárólag az idealizáltság narratíváiban életképes, csak utópiaként létezhet.

Kulcsszavak: emlékezet, identitás, etnikai konfliktusok, Jugoszlávia, titoizmus, nosztalgia 




\section{Szeged}

\section{A részvétnél is mélyebbre (Egy „aszketikus ínyenc” Jugoszlávia-képéről)}

I elkes magyarországi propagátora, Németh László, továbbá Zágrábban élő barátja, Sinkó Ervin mellett Fejtő Ferencről szintén szólván, naplójának tanúsága szerint Miroslav Krleža az alábbiakat tartotta lejegyzésre érdemesnek 1958. január 29-én: „Fejtő könyve, az Érzelmes utazás (1937) elkallódott valahol. Ez volt az első hang Horthy Magyarországából”. ${ }^{1}$ Gyors kiegészítésül és eligazításul hozzáfüzve, hogy „Fejtőt ma Párizsban, mint a balkáni, Duna menti és kelet-európai kérdések szakértőjét tartják számon.”2 A régi Zágráb lüktető ritmusát és magnetikus vonzását a rokonsági kapcsolatai révén Fejtő Ferenc már elemi iskolás korában, helybéli ifjonccá avanzsálva megtapasztalhatta. Fokozatos beemelődése egy másik kultúra értékrendjébe, mindennapi joggyakorlatába s az otthoniétól eltérő élőnyelvi forgatagába nem szakadt meg kamasszá cseperedése közepette sem, közvetlenül befolyásolván világérzékelése kapuinak egyre szélesebbre tárulását. A történelmi, a művészeti, az irodalmi, a közéleti alapismeretekben megmártózva, a lokális viselkedésmintákhoz, az urbánus folklórhoz szokva edződött a horvátság központjának gazdasági és szociális miliőjében. Gyakori visszatérőként, vaká-

1 Miroslav Krleža, „Napló 1958-1969: részletek”, vál. és ford. Túri Gábor, Híd 46, 7-8 (1982): 852. A hiányolt mű datálása pontatlan, a kötet hamarabb jelent meg.

2 Miroslav Krleža, „Napló 1958-1969: részletek”, 853. 
ciózóként bőven elegendő inspirációt gyűjtött ahhoz, hogy a térséghez, a szerette városhoz való viszonyát a cselekvései stilizáltan feldolgozott emocionális kötődésein, műveltségi szimpátiáin átszűrve tálalhassa majdani önéletrajzi munkáiban, esszéisztikus történelmi tablóiban, újságírói elemzéseiben.

A Nyugat 1935-ös évfolyamának 11. számában publikált Zágrábi utinaplójából nagyobb lélegzetűen kiérlelt Érzelmes utazás dalmáciai és montenegrói tengeri élményekkel, hangulatleírásokkal egybefont regényes visszaemlékezés. A múfaji szétszálazódásából erényt kovácsolóan a gyermekkori agrami benyomásokat vegyíti a beérkezés küszöbén álló fiatalember elméleti fejtegetéseinek sorával az erkölcsi és az etikai normákról, a polgári létkilátásokról, az együtt élő nációk lappangó ellentéteiről. Olyan magánbeszélgetések felelevenítésével és közbeékelésével, amelyeket különböző nevezetes személyekkel folytatott Laurence Sterne népszerű, tizennyolcadik századi művét (A Sentimental Journey Through France and Italy) idéző jártában-keltében. A Nagykanizsáról elszármazó, a szülőföldjének Batthyány Lajos nádor alapította és a piaristák vezetésére bízott patinás oktatási intézményében érettségiző, ${ }^{3}$ egyetemi éveit Pécsett és Budapesten töltő szerző számára Zágráb mindig a biztos hazaérkezés helyszíne maradt, hiába változott annyiszor régiós besorolása, rangja és jelentősége. „Szülővárosom vagy, Zágráb, pedig nem benned születtem, mégis a te öledben érzem magam csak egészen otthon. Megmaradni nem tudnék benned, élni nem tudnék itten, hiszen idegen a néped, más a nyelve is, és a sorsa is más, bár hasonló."4

A több nemzetiséget magába fogadó nagyváros lakói, mindenekelőtt a horvát ajkúak iránti odaadását az országokon, határokon átívelő családi múlt historikus rétegzettsége és a huszadik századi jelen drámai fordulatai együttesen határozták meg. Nacionális sorskérdéseket összeszikráztató korszakok felfutásának-leáldozásának szemtanújaként és krónikásaként látott rá azokra a mozzanatokra, illetve élte át, csoportosította részletezően ama fejleményeket, eseménytorlódásokat, amelyek a kérészéletű parlamenti rendszertől vezettek az egymásra lövöldözésekkel, gyilkosságokkal felbolygatott monarchista diktatúrához meg a katonai puccshoz, majd a sztálinista nyomásgyakorlástól tovább pörögtek a szocialista tervgazdálkodásig, hogy onnan a szabadság és a tolerancia fojtogató látszatengedményeivel teletúzdelve érkezzenek el a nyitott államhatárok delíriumos csodájáig, tömeghipnózisáig.

Az előbbiekben említett és kiindulópontul szolgáló nemes krležai gesztus, a maga nemzetközi reputációt méltató, a tájékozottságot, a szakavatottságot elismerő jellemzésével annyira imponált Fejtő Ferencnek, hogy az Érzelmes uta-

3 Zala megye e legrégebbi iskolájába járó diákelődje volt például Virág Benedek, Deák Ferenc, Malonyai Dezső és Hevesi Sándor is.

4 Fejtő Ferenc, Érzelmes utazás: Harmadik, bővitett kiadás, (Budapest: Kossuth Kiadó, 2008), 26. 
zás ötvenhárom év utáni új kiadását indító 1988-as Előszóban szép viszonzással adózott feledhetetlenségének: „A nagy Krleža, aki emlékirataiban oly kedvesen beszél rólam, néhány éve szintén elszenderült.".5 Amikor jó fél évszázaddal korábban tudomást szerzett a „horvát Remarque” létezéséről, a közmegegyezéses művészi kivételességének, a sokak által bírált politikai nézeteinek hírei kapcsán felébredt benne a kíváncsiság, vajon milyen szinkronikus és diakronikus együtthatások fedezhetők fel Miroslav Krleža talányos habitusa és bölcseleti tájékozódásának, szellemi hovatartozásának forradalmár hevületű, anarchista, marxista, kommunista eltolódásai, hangsúlyárnyalódásai között. Annak ellenére izgatta a személyes találkozás eshetősége, hogy nem lehetett kétsége: amikor a jelen homályában élve az adott történelmi időszak és az egyéni léttapasztalat temporális illeszkedései kerülnek terítékre, a kortársi horizont leképezése, eseményeinek, tevőleges szereplőinek minősitése mindig kockázatos lépésnek számít, fölöttébb elhamarkodott döntési mechanizmusnak bizonyul.

A távolságtartó, a riportszerű kérdésekre ímmel-ámmal felelgető írófejedelem az eleinte akadozó társalgásból végül olyan tartalmas, Ady Endre költészetét gyújtópontba állító magyarságismereti kiselőadást csiholt, amelynek hatása alól Fejtő Ferenc - akármennyire igyekszik elhallgatni - nem tudta kivonni magát. Kétszer is leszögezi, milyen kimagasló, európai formátumú tekintéllyel akadt dolga, s noha fennen hangoztatja, hogy „írásaiba valami ősi, barbár, vérszomjas keserüség is betolakodott, valami kétségbeesett izzás, délszaki forróság”, 6 pusztán a bennfentesség látszatát tudja fenntartani úgy téve, mintha a szövegvilágába szorgalmasan beleásta volna magát, holott az efféle intellektuális tüsténkedést nem vitte túlzásba miatta. Őt a „dél Ibsene” (a sok közül egy másik elhíresült becenevét se feledjük) nem szépíróként foglalkoztatta elsősorban, hanem közéleti motiváltságú értelmiségi típusként, a fiatalság bálványozta polgárpukkasztóként és könyörtelen hatalomkritikusként. Aki úgy képes a szabad alkotómunkát piedesztálra emelni, hogy hasonszőrű pályatársait, a tilalmakkal dacolni kész követőit bátorítja fel a véleménymondás és a múvészi teljesítmény korlátozhatatlanságáért síkra szállva; a stílusok szimultaneitásáért felelősséget érezve, vagy éppen a kultúra szovjetizálásának ellenében keményen szót emelve, miként a Jugoszláv Írószövetség III. Kongresszusán Ljubljanában nyilvánosan megtette 1952. október 5-én. Ugyanezen év novemberében, a Jugoszláv Kommunisták Szövetségének VI. Kongresszusán az AFP hírügynökség tudósítójaként ugyanott kiküldetésben tartózkodva Fejtő Ferenc megint összefutott és parolázott vele. Bár főleg az érdekesnek ígérkező pletykákról tájékoztatta, a generalisszimuszról terjesztett viccekkel örvendeztette olvasóit, nyilván nem maradtak előtte ismeretlenek ezek a körülmények sem.

5 Fejtő Ferenc, Érzelmes utazás, 14.

6 Fejtő Ferenc, Érzelmes utazás, 129. 
Amikor azon a sok évvel előbbi, július 23-ai találkozási napjukon felfedte utazási, Fiume és Kotor közötti hajókirándulási tervét, támogatásul megkapta Miroslav Krleža egyik kedvenc képzőmúvésze és bizalmas barátja címét, aki a Dubrovnik melletti Mliniben szokott nyaranta időzni. A történet szúkitett és bővített változatban egyaránt olvasható munkáiban; először az Érzelmes utazás kalandkereső vándoraként adta elő zanzásítva, másodszor pedig a Budapesttől Párizsig - Párizstól Budapestig című könyvében tért ki rá, a kifelejtett epizódokat körültekintően dokumentálva, a homályban hagyott momentumokat tüzetesebben boncolgatva. A „legnagyobb élő jugoszláv festőnek"7 aposztrofált és mindössze a nevének kezdőbetűivel (P. D.) emlegetett alkotóról meg a vele folytatott szívélyes eszmecseréről beszámolván - talán politikai elővigyázatosságból, talán cenzurális veszélyérzetből -, talányos és diszkrét megfogalmazásokkal hozakodott elő. Jelezve például, hogy az illetőt „egy közép-európai államban forradalmársága miatt halálra ítélték”, 8 s aki a francia fővárosban kikötve „sokat volt magyarok között, s egy fiatal, nagy ádámcsutkájú, gamin külsejü, bozontos hajú"9 költővel közelebbi ismeretségbe bonyolódván, többször együtt időzött.

Angyal Endre volt az, akinek sikerült felfigyelnie erre a krležai sugalmazású vizitálásról szóló híradásra. Ő oldotta fel Petar Dobrović monogramját, a Párizsban felbukkanó poétát könnyedén azonosította József Attila személyében, valamint korrigálta a névjegyét Dobrovits/Dobrovics Péterként szintén letevő, pécsi születésű vendéglátóhoz, a bányászváros szerb megszállásának megszüntetésekor kikiáltott Baranya-bajai Szerb-Magyar Köztársaság (1921. augusztus 14. - 1921. augusztus 21.) rövid ideig ügyködő elnökéhez köthető valóságtartalmakat: „Dobrovićot sohasem ítélték halálra, s a pécsi katonalázadást sem ő szervezte, csak részt vett benne. Valószínúleg a beszélgetés is magyarul folyt, nem franciául, hiszen a vajdasági származású Olga asszony is értette ezt a nyelvet."10 Az először 1986-ban franciául megjelentetett Mémoires de Budapest à Paris, majd ennek kiegészítettebb magyar nyelvű változatai (1990, 2007) jóval bőbeszédúbbek, a Mliniben zajló pihengető állomásozás tényszerübb és tágabb kereteket kap, az adatpontosítások, név-konkretizációk kerekebb egésszé teszik. Hallomásból, közvetett információkból (Nagy Csaba nevű barátjának köszönhetően) Fejtő Ferencnek tudomására jutott az érdemdús szlavista kutatói teljesítménye, jóllehet Angyal Imrévé keresztelte át (a kötetszerkesztő és a fordító kettős szégyenére ez így is rögzítődött), melynek sajnálatos folyományaként a hiánypótló disszertáció alcíme sem tudott

\footnotetext{
7 Fejtő Ferenc, Érzelmes utazás, 172.

8 Fejtő Ferenc, Érzelmes utazás, 171.

9 Fejtő Ferenc, Érzelmes utazás, 173.

${ }^{10}$ Angyal Endre, Petar Dobrović: Az ember, múvész és politikus, (Pécs: Magyar Tudományos Akadémia Dunántúli Tudományos Intézete /Közlemények 3./, 1968), 53.
} 
illendő módon citálva összerendeződni, hiszen hibásan, „az ember, a festő és a politikus"-ra ${ }^{11}$ átcserélve hivatkozik rá a szerző.

Petar Dobrovićról a húszas évek Párizsában beléje botló és vele párbeszédbe elegyedő, eredetileg pécsváradi kötődésű Tamás István produkálta az első komplettebb jellemzést, a Kosztolányi Dezső előszavával bevezetett beszélgetés-gyűjteményében: „Csupa tǔz, lendület és aktivitás. Ahogy beszél, ahogy gesztikulál, végig árad rajta a harcos idők nyugtalansága, amely élére robbantotta őt egy mozgalomnak, amely a fantázia világából a realitások kardokkal és szuronyokkal bélelt országútjára dobta a lávaszívű embert. Micsoda bizarr ötlet: egy költői festő, puskával a kézben és mögötte a halálra kész tömeg. Én láttam őt 1921-ben, Pécsett, azon a történelmi napon, amikor a bányák népei mind a zászlaja alá sereglettek, lecsapta az ecsetjét, és végigcsinált egy olyan bravúros mozgalmat, amely példátlanul áll a képzőmúvészet történelmében."12 Miniatűr pályaszakasz-magasztalása természetesen nem siklott át földijének a mesterségéhez fűződő poétikus ragaszkodása felett sem: „Soha szülőföldemen kívül nem festettem tájat, csak Dalmáciával tettem és teszek kivételt. Fantasztikusan szép városok, márvány paloták még a XII-XVIII. századból. Negédes, piktornak való romantika!"13 Hármójuk dunántúli illetőségü összekapcsoltságából nézvést persze még szembeötlőbb, mennyire oldott belemerüléssel, simulékony belehelyezkedéssel térképeztetik fel Fejtőnél a formák közé határt húzó grafizmus elhagyásának múvészi gesztusa, a színés anyagérzékelés képi artikulációjának ${ }^{14}$ dobrovići kivételessége. A múzsául és modellül választott Olga Hadžival, mint örök fénysugárral a centrumban, akit „Mona Lisa tartású”15 házastársnak, a „szerb Giocondának”16 hív az adriai partvidék lenyűgözte átutazó, amit a Budapesttől Párizsig - Párizstól Budapestigben megfejel a fiatal asszonyka bájainak kitartó ámulatával, hiszen „olyan formás volt, mint egy megelevenedett Bourdelle-szobor". ${ }^{17}$

Az Érzelmes utazás mediterrán térségeken keresztüli zarándoklatot tartó főhőse felfokozott nyitottsággal és befogadó készséggel, a jólét, a bőség, a béke örömeire vágyakozás Árkádia-látomásában ${ }^{18}$ osztozva mozog a vízimalmokból átalakított mlini mini-paradicsomban. Szenzitivitása nemcsak a Kazinczy

\footnotetext{
${ }^{11}$ Fejtő Ferenc, Budapesttől Párizsig - Párizstól Budapestig: Visszaemlékezések és beszélgetések, ford. Balabán Péter, (Budapest: Kossuth Kiadó, 2007), 158.

12 Tamás István, „Petar Dobrovics”, in T. M., 5 világrész a Szajna partján, (Subotica: Minerva RT., 1927), 163.

13 Tamás István, „Petar Dobrovics”, 162.

${ }^{14}$ Vö. Ješa Denegri, „Petar Dobrović i Dubrovnik”, in J. D., Modernizam/Avangarda: Ogledi o međuratnom modernizmu i istorijskim avangardama u jugoslovenskom umetničkom prostoru (Beograd: Službeni glasnik, 2012), 86.

15 Fejtő, Érzelmes utazás, 173.

${ }^{16}$ Fejtő, Érzelmes utazás, 174.

${ }^{17}$ Fejtő, Budapesttől Párizsig - Párizstól Budapestig, 157.

18 Vö. Denegri, „Petar Dobrović i Dubrovnik”, 86.
} 
Ferenc jóvoltából Érzékeny útazások Franczia- és Olaszországbannak magyarított Laurence Sterne-i mú hívéül, modernkori követőjéül szegődöttségében érhető tetten, hanem e friss artisztikus impulzusok, múvészetpszichológiai kihívások élénkítette reakcióiban is. „Azt hisszük, hogy Fejtő itt jól megragadta Dobrovićnak, az embernek, múvésznek és politikusnak egész habitusát. A találkozás és beszélgetés leírásában is nagyon jó a környezet, a festőt inspiráló dalmáciai ambiente, valamint magának a múvésznek, testi külsejének, lelkialkatának bemutatása"19 - nyomatékosította Angyal Endre erről a meggyőzően kibontakozó aprólékosságról és szakszerűségről nyilatkozván.

A másik felé odafordulás rokonlelki következetességének, a forma- és alakszemlélet iránti elkötelezettségének színvonalát emeli, hogy a témakezelést illetően, sőt az esztétikai igényességet tekintve szintúgy egybecsendül azzal a művészi önértelmezéssel, a saját műhelytitkokat felvillantó beavatással, amelyek az apai ágon ugyancsak nagykanizsai gyökerekkel rendelkező Petar Dobrović szájából elhangzóan híresültek el. Miroslav Krleža nyomán szerezhetni tudomást erről a saját látásmódot érintő lélekbányászatról, hiszen agrami gyermekkorához visszakanyarodó emlékirataiban (Djetinjtsvo u Agramu 1902-03, Zagreb, Zora, 1952) ő számolt be autentikus közvetítőként művészkortársa és barátja hitvallásáról, amit a jellegzetes mondatok evokálásával rövidesen szó szerint megismételt az életművének szentelt kismonográfiájában (Petar Dobrović, Zagreb, Zora, 1954). Fültanúi tolmácsolása alapján „Petar Dobrović így beszélt: számomra a kép kolorisztikus tömeg. Ugyanezt a kolorisztikus masszát szemlélem a tárgyon is, amit festek, tehát nem arranzsálom a képemet, hanem egyszerüen átviszem a vászonra úgy, ahogy véleményem szerint valóságosan is létezik. A kolorisztikus tömegek felfokozása az objektumon: ez a programom, amihez mindenáron ragaszkodom. [...] Az embereknek olyannyira nem hízelgek, hogy minden pillanatban kész vagyok karikírozni őket. Az ember számomra architektonikus jelenség, kevésbé fontos lélektani mozzanatokkal, egy olyan megvilágításban, amelynek intenzitását, amennyire csak tudom, fokozni kívánom."20

A déli szláv térséget benépesítő etnikumok főbb ismertetőjegyeit, küllemi adottságait, spirituális rezdüléseit, vérmérsékleti és ösztönéleti különbségeit górcső alá vevő Fejtő Ferenc-i passzusok előszeretettel, de nem fantáziátlanul operálnak a szokásos sztereotípiákkal, a délceg horvátok megtörhetetlen ellenállási kedvét és mozgalmi pátoszát, a szilaj szerbek megfélemlíthetetlenségét és lekenyerezhetetlenségét, a büszke szlovénok mértéktartását és európai műveltségét, a montenegróiak párját ritkító konokságát, széles gesztusok mögé rejtett csavaros észjárását bizonygató általánosításokkal. A rész-

\footnotetext{
${ }^{19}$ Angyal, Petar Dobrović, 53.

20 Miroslav Krleža, „Agrami gyermekkorom 1902-1903”, ford. Ács Károly in M. K., Versek, Emlékiratok, ford. Ács Károly, Csuka Zoltán, (Budapest: Európa Könyvkiadó, 1965), 248-249.
} 
véttel teli érdeklődését kiváltó találkozásokkor „megjelennek emberek, igaz gyakran mint jellegtelen tömeg, de az is előfordul, hogy miután egyikük kiválik a csoportból, egyéni tulajdonságokat nyer, sőt még párbeszédet is folytat az íróval." ${ }^{21}$ A társadalompolitikai szerkezetrezgéseket, illetve a közösségmegtartó alaphelyzetek visszaállíthatóságát vagy újrateremthetőségét a háborús konfliktusok és a fals etnikumközi tolerancia tükrében igyekezett vizsgálni. A politikai elitek erős nacionalista karakterét a szocio-morális kötelékek meglazulása, értékdevalválódása miatti aggodalommal tanulmányozta. Évtizedeken át latolgatva, színéről és visszájáról körbejárva mindazt, ami a többségi és kisebbségi státusokba kapaszkodások, a centrális és perifériális pozícióváltások következményeként a számára oly kedves horvátok kárára zajlódott le, s a Bácskában, a Bánátban, Szlavóniában, a Drávaszögben és a Muravidéken élő magyarság hercehurcáit súlyosbítva járult hozzá a mindig puskaporos hordónak tekintett övezet különféle uralmi fennhatóságokat, eltérő államformákat váltogató territoriális agóniájához.

Két másik kultikus figura magaslik ki nála látványosan a végletesség balkáni dimenziójából. A Budapesttől Párizsig negyedik részében (Megpróbálunk új életet kezdeni), továbbá a Párizstól Budapestig címmel hozzá csatolt, Galló Béla és Márton László közreműködésével megejtett 2006-os beszélgetésben, miként az 1950-es évek második felétől kezdődően az Irodalmi Ujságban, az 1990-es években a Heti Kis Újságban meg az Európai Utasban, halálának évtizedében pedig a Magyar Hírlapban közzé tett szakkommentárjaiban, történelmi-politikai oknyomozásaiban rengetegszer feltűnik Josip Broz Tito és egykori helyettese, Milovan Đilas alakja. Portrészerű pillanatképekből, lényeglátó észrevételekből, de a velük kialakított személyes nexusokra utaló információ-morzsákból, intim adalékokból is merészen csemegézve rajzolódik ki ellentmondásos életútjuk. Az emblematikus partizánvezér, a fényűző öltönyökben és méregdrága díszegyenruhákban parádézó balkáni erősember, kinek bársonykesztyúbe bújtatott vasmarkából ellenlábasként igen kétséges volt a szabadulás, a vallásos gyülöletet elsimító békehozásával, a minden jugoszlávot összeterelő atyáskodásával, tehát az össznépi imádat ${ }^{22}$ koholmányából levezetett mindenhatóságával egymaga testesíti meg a viszonylagos nyitottság és a merev szabályozottság pszeudo-demokráciáját.

A horvát apa és szlovén anya gyermekeként fogant Tito flancoló mivolta, piperkőc jelensége sajátos kontrasztba kerül a csillogó értelmű és heves temperamentumú Milovan Đilas montenegrói karakánságával. Szerepének

${ }^{21}$ Ćurković-Major Franciska, „Zágráb képe Fejtő Ferenc Érzelmes utazás című regényében”, Tiszatáj 56, 10 (2002): 81.

22 Vö. Vjekoslav Perica, „United We Stand, Divided We Fall: The Civil Religion of Brotherhood and Unity", in V. P., Balkan Idols: Religion and Nationalism in Yugoslav States, (New York: Oxford University Press, 2002), 103. 
kedvező megítélésénél sokat nyomhatott a latban, hogy az ő 1947 óta szűkebb plénum előtt és nyilvános fórumokon egyaránt hangoztatott álláspontja a magyar demokrácia támogatásáról, közép-európai léptékben mérvadó győzelemre segítéséről, jócskán harmonizált a fejtői elképzelésekkel. A tartományi népegyesülés és népegyesítés szuggesztiójának megteremtésében és kivitelezésében segédkezése sem volt elhanyagolható, mert a "jugoszláv föderáció belső határait egy Milovan Đilas által irányított bizottság határozta meg 1945-1946-ban". ${ }^{23}$ A koncepciója egy olyan országról, amelyet a nemzeti kisebbségek és a többségi nemzetek vállvetve egymásért munkálkodása a jugoszlávul érzés és morfondírozás keblet dagasztó új tartalmaiban forraszt össze testvériesen, nem kevésbé hathatott üdítően 1953 tájékán. Azonban a titoizmus véres megtorlásairól értesülve, a pártbürokrata új elit mozgalmár-monopóliuma okozta problémákat megütközéssel fogadva hamarosan konstatálnia kellett, hogy a jugoszláviai közállapotokat, az „adminisztratív apparátus egyeduralmát és zsarnokoskodását" 24 bíráló, egy ellenzéki politikai párt létrehozásának szükségességét szorgalmazó Đilast lázító propaganda kifejtésének vádjával 1955-ben másfél évre ítélte (háromévi felfüggesztéssel) a Belgrádi Törvényszék. Erre következett a Magyarország szovjet megszállása ügyében mutatott jugoszláv magatartást kifogásoló véleménye miatti letartóztatása és szigorított fegyházbüntetése 1956-ban, hiszen a tényeket kiforgatóan, rágalmazó szándékkal lépett fel saját országa tekintélyét csorbítandó, népeinek érdekeit semmibe veendő. Nem sok ideje maradt a döntést emésztgetni a Sremska Mitrovicai Fogházba zárva, mert a Nagy-Britanniában és az Egyesült Államokban kinyomtatott könyvéért (The New Class: An Analysis of the Communist System, London, Thames and Hudson, 1957) a helyi körzeti bíróság újabb két évet sózott a nyakába.

Az 1956 novemberében letartóztatott, azóta rács mögött tartott Milovan Đilast 1961. január 20-án helyezik feltételesen szabadlábra. Ennek örömére készített üdvözlőjében Fejtő Ferenc kinyilvánítja, milyen „élesen bírálta a szovjet »felszabadító « csapatok immorális viselkedését, a részeg tisztek garázdálkodását, a Jugoszláviába küldött szovjet »szakértők « arroganciáját”, ${ }^{25}$ s nem palástolja, hogy akinek aktuális megmenekülését ünnepli, a „szókimondó, a kommunista eszményekben őszintén hívő, de az ideológiától el nem vakult, a valósággal szembenéző, az igazságot elveinél is többre becsülő ember

\footnotetext{
${ }^{23}$ Sokcsevits Dénes, Horvátország a 7. századtól napjainkig, (Budapest: Mundus Novus Kft., 2011), 619

${ }^{24}$ Darko Suvin, „The Socialist/Communist Discourse about Bureaucracy /Appendix 2: The Discourse about Bureaucracy and State Power in Post-Revolutionary Yugoslavia/", in D. S., Splendour, Misery, and Possibilities: An X-Ray of Socialist Yugoslavia (Leiden-Boston: Brill, 2016), 351.

${ }^{25}$ Fejtő Ferenc, „Gyilasz szabadon”, Irodalmi Ujság 12, február 3. (1961): 3.
} 
típusaként emelkedik ki”26 kortársai, politikus kollégái közül. Baloldali angazsáltságú szabadságkeresőként persze már 1957-ben átlátott a szitán, hiszen idejekorán feltárta a hadikommunizmusból kikecmergés utáni elnyomó-rendfenntartó szabályok, kényszer- és szükségmegoldások háttérösszefüggéseit: „A valóság azonban az, hogy 1945 óta a polgárháborúból győztesen kikerült kommunista partizánvezetők tartják megszállva a jugoszláv állam minden jelentős politikai, gazdasági és kulturális pozícióját. Ők a minisztériumi fótisztviselők, a bankigazgatók, gyárigazgatók, a rendőr- és katonatisztekről ne is beszéljünk. A jugoszláv proletárdiktatúra neve alatt lényegében partizán diktatúra húzódik meg. Ez az ő rendszerük jellegzetessége az orosz és más kommunista rendszerekkel szemben; ez ad neki nemzeti jelleget, aminthogy az adminisztrátorrá vált volt partizánok összetartása biztosítja a jelenlegi jugoszláv rezsim szinte kivételes stabilitását". ${ }^{27}$

Aligha tűnt bonyodalmasnak rájönnie a turpisságra, hogy a jugoszláv kormány Milovan Đilas elengedésével a hamis képzetek keltésének praktikáihoz folyamodott. Azt akarta lenyomni a honi és a külföldi közvélemény torkán, hogy a „radikális ellenszegülés pionírjának" ${ }^{28}$ szabadon bocsátása tulajdonképpen az irányító hatalom jószántából, demokratikus gyakorlatából fakadó üdvözítő összeredmény, azaz korántsem valamilyen elszigetelten tisztázott és megoldást nyerő kérdés, hanem a politikai okoknál fogva lakat alatt tartott személyek társadalmi reintegrációjának részfejleménye, előjátéka csupán. A „montenegrói fenegyerek" ${ }^{29}$ Beszélgetések Sztálinnal (Conversations with Stalin, New York, Harcourt Brace Jovanovich, 1962) című kötete miatti ismételt lefogásának, és ötévi, az előző itéleteivel összevonva immár összesen tizenhárom évi börtönbüntetésének hírére Fejtő Ferenc így csak a direkt a đilasi renitensség megfékezésére kiókumlált törvényerejü rendelkezések miatti megdöbbenéssel reflektálhatott: „akármilyen jogi érveket mozgósít is az állam- és párt-rezón eljárásának igazolására, a tény az, hogy ismét szájkosarat raknak egy olyan emberre, akinek szókimondó bátorsága, szenvedélyes igazságszeretete eddig csak dicsőséget hozott népének és hazájának" ${ }^{30}$

Milovan Đilas civil kurázsija, a kommunista nómenklatúra életstílusa elleni támadása, azzal egyetemben, hogy a burzsoá értelmiségiek itták a szavait, az egyetemista diákok tömegei rajongtak érte, fölöttébb tetszhetett Fejtő Ferencnek, nem utolsó sorban azért, mert kifejezetten ugyanezek zavarták és gerjesztették éktelen haragra Josip Broz Titót. Az Irodalmi Ujságban publikált 1960-as évekbeli cikkei a jugoszláv semlegességi irányvonal ipari felzárkózásra, javuló

\footnotetext{
${ }^{26}$ Fejtő Ferenc, "Gyilasz szabadon”, 3.

${ }^{27}$ Fejtő Ferenc, „Belgrádi levél”, Irodalmi Ujság 8, augusztus 1. (1957): 2

${ }^{28}$ Suvin, „The Socialist/Communist Discourse about Bureaucracy”, 352.

${ }^{29}$ Fejtő Ferenc, "Gyilasz”, Irodalmi Ujság 13, április 15. (1962): 5.

30 Fejtő Ferenc, "Gyilasz", 5.
} 
piacgazdasági mutatókra vonatkozó önigazolásait (A jugoszláv gazdasági elképzelések, 1962. május 15.), a Jugoszláv Kommunista Szövetséget az imperialistákkal kokettálás dacára is testvérpárti ölelésben részesitő szovjet megenyhülést (Hruscsov Titót választotta, 1963. január 1.), a Nyugattal és Amerikával odaadó partnerként lejtett marsalli tánclépéseket (A jugoszláv kommunisták kongresszusa, 1965. január 1.), illetve a másként gondolkodókat vegzáló rezsim rendezvényeket akadályozó, irodalmi-múvészeti folyóiratokat felszámolgató-betiltogató machinációit (Jugoszlávia fordulóponton, 1965. január 15.) veszik számba. A szlovén magazin, a Perspektive (fejtői tévesztéssel-elírással: „Perspektiva”) szerzőinek és szerkesztőségének vétkéül a polgári létmód értékeinek védelmét, a többpártrendszer visszaállításának óhaját, no meg a sztrájkoló ljubljanai munkásoktól, a vonalas kormányzás miatt háborgó diákoktól feléjük áradó bizalmat és szeretetet rótták fel, amiért két elismert szépírónak feltétlenül lakolnia kellett. Tomaž Šalamunt és Marjan Rožancot (szerzőnk ez utóbbi vezetéknevét megemlíti ugyan, ám az ékezetnek se híre, se hamva) a bevett büntetés-végrehajtási elkülönítéssel ki is vonták a forgalomból.

A jugoszlávizmus, a jugonacionalizmus, a nemzeti kommunizmus és az etnikai integralizmus irracionalitása sohasem maradt kétséges Fejtő Ferenc előtt, maga sem hihetett komolyan a többkultúrájúság édenkertjének létezésében. A Nyugat és az USA fogadott gyermekeként pátyolgatott Jugoszlávia terülj-terülj asztalkáját körülzsongó kiváltságosságban, a Disney World és Legoland önfeledten vidám szórakozás-kevercsét porciózó sokszínűségben szinte bármi megadatott, ami szem-szájnak ingere. Viszont a pattogó mázú díszletek határolta kavalkádban, a műanyag védőburokba gubózások közepette az ott élő népeknek számtalan próbatételen kellett átesniük, mindent kikísérleteztek rajtuk, ami egzisztenciális, nyelvi-kulturális téren, világnézeti, gazdaságszervezési és társadalomtervezési célzattal, honvédelmi és fegyverkezési révületbe ejtéssel megoldhatónak mutatkozott. Nem véletlenül találta indokoltnak egy a kollektív felocsúdásra bíztató prominens szlovén író-értelmiségi a „Titoszlávia” meghatározást, a "Titoland" márkajelzést 1991-ben, a közel háromnegyed évszázadnyi fennállása utáni összeomláshoz érkezett államalakulat detronizálóan sallangmentes névvel ${ }^{31}$ illetésére.

A szociáldemokrata beállítottságát, a marxizmusát és a magyar patriotizmusát harcos európai hazafiságra változtató átalakulását, világpolgári derekasságát sűrűn felemlegető Fejtő Ferenc diplomatikus filantrópiája, béketeremtő orientációja régi lendületével és emelkedettségével kapott szárnyra az 1990-es években, amikor a nacionálkommunizmus totalizáló őrületét, a militáns területfelosztást és a származási, felekezeti alapú szomszédirtást (A szerb nem-

\footnotetext{
${ }^{31}$ Vö. Drago Jančar, „Emlékek Jugoszláviáról”, ford. Orsolya Gállos in Az eltört korsó: Válogatás a legújabb szlovén esszéirodalomból ford. Orsolya Gállos, Judit Reiman (Pécs: Jelenkor Irodalmi és Művészeti Kiadó, 1992), 114. és 121.
} 
zeti kommunizmusról /Az „etnikai tisztogatás” ideológiai forrásai/, 1993. május 7.) taglalja a Heti Kis Újság hasábjain. Az önállósodási szándékokat megtorpedózó hegemonisztikus igyekezetet rosszalló, a hagyományok sárba tiprását és az emberi jogok semmibe vételét elutasító aufklérista humanistaként azok közé tartozott, akik a horvátokkal szolidarizálva „felismerték a miloševići törekvésekben rejlő veszélyt, és támogatták a horvát függetlenség ügyét". ${ }^{32} \mathrm{~A} \mathrm{Ma-}$ gyar Hírlapnak adott interjújában („A szerbek vesztettek”, 1993. június 14.), Szalay Hannának válaszolgatván a Nyugat forszírozta helyreállítási forgatókönyv szerinti föderációt, a tagköztársasági szinten egyenként szárba szökkentendő demokráciákat nevezte meg a közép-kelet-európai előrehaladás biztosítékaiul. A problémákat orvoslás fiatalkori zágrábi eszménye köszön itt vissza a horvát szuverenitás letéteményeséhez, a centralista uralmi praxis elleni tiltakozásra és a passzív rezisztenciára ösztönző Vladko Mačekhez kapcsolódóan.

Az 1930-as évek legvégén a „horvát-szerb kiegyezés tető alá hozása horvát részről Vladko Maček parasztpárti politikus érdeme" ${ }^{\prime 3}$ volt, amire áttételesen már a címével utal a Magyar Hírlap egyik 2001-es nyári lapszámában napvilágot látott rövid analízise a boszniai bonyodalmakat szem előtt tartó megegyezési esélyekről. Az illetékességet vállaló külügyi rátermettségről, a Nyugat kompetenciájáról alkotott felfogása lényegesen visszafogottabbá mérséklődött ekkorra, amit évekkel korábban előrevetített a bizalmi tőkéje megkopását sugalló belátás: „A jugoszláv tragédia világítja meg legélesebben, milyen borzalmakhoz vezethet az, ha bürokratikus-katonai eszközök segítségével használják ki a hatalomvágy és az idegengyűlölet eltemetettnek vélt szenvedélyét, amely a társadalmi és gazdasági bajokból és a demokratikus szemlélet hiányából fakad."34 A horvát és a szlovén autonómia-igények meg a nagyszerb expanziós-törekvések végleg szertefoszlatták a Jugoszláv szövetségi délibábot, ezért lassacskán bele kellett nyugodnia, hogy a föderációs vágyálom legfeljebb illúzióhajhászó anakronizmusként működőképes. Befellegzett „annak a hitnek, hogy tartós békét lehet teremteni a népek megkérdezése nélkül, a nemzeti önrendelkezés jogának megsértésével és a történelmi helyzet nemismeretével". ${ }^{35}$ A hadba lépés, a fegyveres erőszak, a szembenálló felek közötti tessék-lássék lavírozás, miként a szlovén múvész- és zenésztársulás, a Laibach tagjai figyelmeztettek a „párját ritkító kegyetlenkedés metaforájává”36 átlényegülő Jugoszlávia megmentése érdekében átgondolatlanul bevezetett óvintézkedésektől,

\footnotetext{
32 Sokcsevits, Horvátország a 7. századtól napjainkig, 691.

${ }_{33}$ Sokcsevits, Horvátország a 7. századtól napjainkig, 510.

${ }^{34}$ Fejtő Ferenc, „Nemzetek, kisebbségek, Európa”, ford. Osvát Anna, Európai Utas 5, 3 (1994): 15.

${ }^{35}$ Fejtő Ferenc, „A horvát - szerb megegyezés”, Magyar Hírlap, június 8. (2001): 7.

${ }^{36}$ Vladimir Unkovski-Korica, "Conclusion” in V. U-K., The Economic Struggle for Power in Tito's Yugoslavia: From World War II to Non-Alignment (London-New York: I. B. Tauris \& Co. Ltd 2016), 231.
} 
egymást tromfoló nemzetközi beavatkozásoktól viszolyogva: „Egészséges a gazdagoknak és halálos kórság a szegényeknek. A háború a kesztyúit levetett kapitalizmus”. ${ }^{37}$ A „változatos hatóerejü modern és posztmodern (meta) elbeszélések vizuális reprezentációinak képzelettágító rotációjához" ${ }^{38}$ igazodó kajánsággal zászlajukra tűzvén a vi et armis végrehajtott népgardírozások és konfliktuscsillapítások euro-atlanti standardjának katonás heroizmussal harsogható vezény- és jelszavait: „TATI - TITO - TOTO - NATO”39

A dagályos provincializmusok elharapózásának érájában mindezek azzal is jártak, hogy az önazonosság-keresés többmenetes nekigyürkőzéseiben, amelyekben regulaként sosem látszott tarthatónak ama hiedelem, hogy „az embernek mindenáron egyetlen identitásra kelljen szorítkoznia". ${ }^{40}$ Fejtő Ferenc előtt apránként kikristályosodott: a rokonszenvét gyermekkorában elnyert és töretlenül megőrző földrajzi tájék ütközőzónáiban még nem találták fel az ország nélküli nemzet- és létbiztonságot. Ahogy a szupranacionális, ideológiamentes patriotizmust sem, mindössze a nemzet(iség)i tömörülések viharos múltbéli hagyatékából, megroppanó gazdasági teljesítményéből eredő érdeksérelmeket s a rutinszerű vádaskodások körforgásából előhullámzó szektoriális feszültségterhességet. A történelmi leckék megtanította, a családi tradíciók és mozgatórugóik diktálta, a szellemi-kulturális indíttatások táplálta szenvedélyes együttérzésének mértéke és szinteződései ekképpen kitüntetett figyelemre méltók. Ritkaságszámba menő előérzettel sejtette meg, hogy a Josip Broz Tito-i vezérlésú és örökségú Jugoszlávia hatalomtechnikai mechanizmusai, optimista jövőt festő jólét-bálványozásai önmaguk nosztalgikus szimulációját hozták létre, s élt a gyanúperrel, hogy a tökéletes vezető(k)ről szőtt perfekcionista álmok, valamint a délszláv háborúk tapasztalatai arra utalnak, az ilyesfajta értékképzés és visszavágyódás kizárólag az idealizáltság narratíváiban életképes, csak utópiaként ${ }^{41}$ kínálhat támaszt, nyújthat némi vigaszt a rászorulóknak.

37 „Kérdések a Laibach csoportnak (A Rockerilla magazin nyomán)”, ford. Domokos Tamás in Extázis és agónia: Független zenei /h/arcterek, a Fosszília különszáma (VII. évf. 4.), vál. és szerk. Virág Zoltán (Szeged: JABE a Hallgatókért Kiadói Alapítvány-POMPEJI Alapítvány, 2006), 156

38 Mitja Velikonja, "New Yugoslavism in Contemporary Popular Music in Slovenia”, trans. Olga Vuković in Post-Yugoslavia: New Cultural and Critical Perspectives, ed. Dino Abazović and Mitja Velikonja (Basingstoke: Palgrave Macmillan, 2014), 69-70.

39 "Kérdések a Laibach csoportnak (A Rockerilla magazin nyomán)”, ford. Domokos Tamás in Extázis és agónia: Független zenei /h/arcterek, a Fosszilia folyóirat különszáma, vál. és szerk. Virág Zoltán (Szeged: JABE a Hallgatókért Kiadói Alapítvány-POMPEJI Alapítvány, 2006), 157

40 Fejtő Ferenc, „Előszó az Érzelmes utazás új kiadásához, ötvenhárom év után”, in F. F., Érzelmes utazás: Harmadik, bővitett kiadás (Budapest: Kossuth Kiadó, 2008).

${ }^{41}$ Mitja Velikonja, „Mapping Nostalgia for Tito: From Commemoration to Activism,” in Welcome to the Desert of Post-Socialism: Radical Politics After Yugoslavia, ed. Srećko Horvat and Igor Štiks (London-New York: Verso Press, 2015). 


\section{Irodalom}

Angyal Endre. Petar Dobrović: Az ember, múvész és politikus. Pécs: Magyar Tudományos Akadémia Dunántúli Tudományos Intézete /Közlemények 3./, 1968.

Ćurković-Major Franciska. „Zágráb képe Fejtő Ferenc Érzelmes utazás című regényében". Tiszatáj 56, 10 (2002): 77-87.

Denegri, Ješa. Modernizam/Avangarda: Ogledi o međuratnom modernizmu i istorijskim avangardama u jugoslovenskom umetničkom prostoru. Beograd: Službeni glasnik, 2012.

Fejtő Ferenc. „Belgrádi levél”, Irodalmi Ujság 8, augusztus 1. (1957): 2.

Fejtő Ferenc. "Gyilasz szabadon”, Irodalmi Ujság 12, február 3. (1961): 3.

Fejtő Ferenc. „Gyilasz”, Irodalmi Ujság 13, április 15. (1962): 5.

Fejtő Ferenc. „Nemzetek, kisebbségek, Európa”. Ford. Osvát Anna, Európai Utas 5, 3 (1994).

Fejtő Ferenc. „A horvát - szerb megegyezés”. Magyar Hírlap, június 8. (2001).

Fejtő Ferenc. Budapesttől Párizsig - Párizstól Budapestig: Visszaemlékezések és beszélgetések. Ford. Balabán Péter, Budapest: Kossuth Kiadó, 2007.

Fejtő Ferenc. Érzelmes utazás: Harmadik, bővitett kiadás. Budapest: Kossuth Kiadó, 2008.

Jančar, Drago. „Emlékek Jugoszláviáról”. Ford. Orsolya Gállos. In Az eltört korsó: Válogatás a legújabb szlovén esszéirodalomból. Ford. Orsolya Gállos, Judit Reiman, Pécs: Jelenkor Irodalmi és Művészeti Kiadó, 2002.

„Kérdések a Laibach csoportnak (A Rockerilla magazin nyomán)”. Ford. Domokos Tamás. In Extázis és agónia: Független zenei /h/arcterek, a Fosszília folyóirat különszáma, vál. és szerk. Virág Zoltán, Szeged: JABE a Hallgatókért Kiadói Alapítvány-POMPEJI Alapítvány, 2006.

Krleža, Miroslav. „Agrami gyermekkorom 1902-1903”. Ford. Ács Károly. In M. K., Versek, Emlékiratok. Ford. Ács Károly, Csuka Zoltán, Budapest: Európa Könyvkiadó, 1965.

Krleža, Miroslav. „Napló 1958-1969: részletek”. Vál. és ford. Túri Gábor, Híd 46, 7-8 (1982): 849-936.

Perica, Vjekoslav. Balkan Idols: Religion and Nationalism in Yugoslav States. New York: Oxford University Press, 2002.

Sokcsevits, Dénes. Horvátország a 7. századtól napjainkig. Budapest: Mundus Novus Kft., 2011.

Suvin, Darko. Splendour, Misery, and Possibilities: An X-Ray of Socialist Yugoslavia. Leiden-Boston: Brill, 2016. 
Tamás, István. 5 világrész a Szajna partján. Subotica: Minerva RT., 1927.

Unkovski-Korica, Vladimir. The Economic Struggle for Power in Tito's Yugoslavia: From World War II to Non-Alignment. London-New York: I. B. Tauris \& Co. Ltd., 2016.

Velikonja, Mitja "New Yugoslavism in Contemporary Popular Music in Slovenia." Trans. Olga Vuković. In Post-Yugoslavia: New Cultural and Critical Perspectives, edited by Dino Abazović and Mitja Velikonja, Basingstoke: Palgrave Macmillan, 2014.

Velikonja, Mitja. 2015. „Mapping Nostalgia for Tito: From Commemoration to Activism". In Welcome to the Desert of Post-Socialism (Radical Politics After Yugoslavia), edited by Srećko Horvat and Igor Štiks, London-New York: Verso Press, 2015.

\section{Dublje i od sućuti (O slici Jugoslavije jednog „asketskog sladokusca”)}

Tijek misli ispituje suodnos između Fejtöve potrage za vlastitim identitetom, njegove intelektualne orijentacije i političkih simpatija. Pri tome se uzimaju u obzir duhovno-kulturne konture autorove koncepcije u kojoj se ovaj naš prostor pojavljuje kao naročito regionalno razvedena, metaforička organizacija dvadesetog stoljeća, i to kao konglomerat historijskog naslijeđa nacionalnih i manjinskih grupacija osuđenih na skromnije dimenzije i ovisnost o sve slabijem gospodarskom zaleđu. Poseban naglasak dobiva fejtövska slutnja da su jezično-retorički i mehanizmi izgradnje vlasti u Jugoslaviji pod upravljanjem Josipa Broza Tita i nakon njega zapravo sami po sebi stvorili nostalgičnu simulaciju. Doduše perfekcionistički snovi tkani o savršenoj državi i savršenom(im) vođi(ama), kao i iskustva južnoslavenskih ratova upućuju na to da je tvorba vrijednosti takve vrste i čežnja za povratkom ostvariva isključivo samo u narativi idealizacije, odnosno da može postojati samo kao utopija.

Ključne riječi: sjećanje, identitet, etnički konflikti, Jugoslavija, titoizam, nostalgija 